\title{
Los retratos del conflicto en la película Oriana*
}

\author{
Luis Fernando Gasca Bazurto*
}

Recibido: 20 de marzo de 2016 -Aprobado: 20 de abril de 2016

\section{Resumen}

Los retratos en el filme Oriana (Torres, 1985) son signos del conflicto que manifiestan una forma de pensamiento que atraviesa a los personajes de la historia y desencadenan un desenlace fatal que los marca para toda la vida. Se analiza la película de Torres (1985) para identificar los signos, las fuerzas y tensiones que se manifiestan y que podrían explicar el porqué de los acontecimientos y el desenlace de la historia. Para ello, se propone la observación de dos retratos que se presentan en el filme. El primero es el retrato pictórico del padre, que se basa en la descripción que hace Moreno (1975), pero representado de una manera distinta y delimitado a un espacio diferente al que expone el texto literario. El segundo es la fotografía de la familia, que abre el filme y que es antecedida por el relato de los acontecimientos que acaecieron durante su registro. Los cuadros mencionados son signos que exponen relaciones de poder y dominio del padre sobre su familia, los cuales provocaron la trasgresión del orden instituido.

Palabras clave: cinema, clase, comparación, ideología, Latinoamérica, literatura, retratos.

Artículo de reflexión. Producto de la investigación que se está llevando a cabo en el curso del trabajo de grado: Los signos del conflicto en el cuento Oriane, Tía Oriane (1975) y en la película Oriana (Torres, 1985), para optar al título de Magíster en Literatura y Cultura. DOI: http://dx.doi.org/10.15332/s0120-8454.2016.0089.03

* Realizador de cine y televisión de la Universidad Nacional de Colombia. Candidato a magíster en Literatura y Cultura del Instituto Caro y Cuervo de Bogotá. Vinculado en calidad de profesor e investigador a la Corporación Unificada Nacional de Educación Superior (CUN). Grupo de investigación Codim. Dirección postal: Av. Kr. 40 \# 25-79, apto. 501. Correo electrónico: luis_gasca@cun.edu.co. 


\title{
The portraits of conflict in the film Oriana
}

(Torres, 1985)*

\author{
Luis Fernando Gasca Bazurto**
}

\section{A bstract}

The portraits in the film Oriana (Torres, 1985) are signs of conflict that show a form of thought that goes through the characters in the story and trigger a fatal outcome that marks them for life. The goal of this analysis is to identify the signs, the forces and tensions that occur and could explain the events and the outcome of the story. To do so, the analysis of two portraits presented in the film is proposed. The first one is the pictorial portrait of the father that is based on the description by Moreno (1975), but represented in a distinct way and defined to a different space, in comparison with the text. The second is the family photograph that opens the film, preceded by the events that occurred during the shooting. Those pictures expose relationships of power and domination of the father over his family that caused the transgression of the established order.

Keywords: Cinema, class, comparison, ideology, Latin America, literature, portraits.

\footnotetext{
* Reflection paper. Product of a research carried out for the thesis entitled: Los signos del conflicto en el cuento "Oriane", Aunt Oriane (1975) and in the film "Oriana" (Torres, 1985) to obtain the title of Master in Literature and Culture. DOI: http://dx.doi.org/10.15332/s0120-8454.2016.0089.03

** Producer of films and television from Universidad Nacional de Colombia. Candidate to Master's degree in Literature and Culture of Instituto Caro y Cuervo in Bogota. Professor and researcher of Corporacion Unificada Nacional de Educacion Superior (CUN). Codim research group. Address: Av. Kr. 40 \# 25-79, apt. 501. Email: luis_gasca@cun.edu.co.
} 


\title{
Les portraits du conflit dans le film Oriana*
}

\author{
Luis Fernando Gasca Bazurto**
}

\section{Résumé}

Les portraits dans le film Oriana (Torres, 1985) sont des signes du conflit qui manifestent une forme de pensée qui traverse les personnages de l'histoire et déchaînent une fin fatale qui les marque pour toute la vie. On analyse le film de Torres (1985) afin d'identifier les signes, les forces et les tensions qui se manifestent et qui pourraient expliquer le pourquoi des faits et du dénouement de l'histoire. Pour cela, on propose l'observation de deux portraits qui se présentent dans le film. Le premier est le portrait pictural du père, qui se base sur la description que fait Moreno (1975), mais représenté de manière différente et délimité à un espace différent à celui présenté dans le texte littéraire. Le deuxième est la photographie de la famille, qui ouvre le film et qui est précédée par le récit des faits qui ont eu lieu pendant son registre. Les portraits mentionnés sont des signes qui exposent les relations de pouvoir et de domination du père sur sa famille, lesquels provoquent la transgression de l'ordre institué.

Mots clés: Cinéma, classe, comparaison, idéologie, Amérique Latine, littérature, portraits.

Article de réflexion. Produit de la recherche qui se déroule dans le cadre de la rédaction de la thèse: Los signos del conflicto en el cuento Oriane, Tía Oriane (1975), Les signes du conflit dans le conte Oriane, Tante Oriane (1975), et dans le film Oriana (Torres, 1985), afin d'obtenir le diplôme de Magister en Littérature et Culture. DOI: http://dx.doi. org/10.15332/s0120-8454.2016.0089.03

* Réalisateur de cinéma et télévision de l'Université Nationale de Colombie. Candidat au Magister en Littérature et Culture de l'Institut Caro y Cuervo de Bogota. Professeur et chercheur à la Corporación Unificada Nacional de Educación Superior (CUN), Corporation Unifiée Nationale d'Éducation Supérieure. Groupe de recherche Codim. Adresse postale: Av. Kr. 40 \# 25-79, apto. 501. E-mail: luis_gasca@cun.edu.co 


\section{Introducción}

La revista ECO de Bogotá publicó, en 1975, el cuento Oriane, Tía Oriane, que fue escrito por la barranquillera Marvel Moreno. En 1985, la venezolana Fina Torres adaptó el relato de Moreno (1975) en la película Oriana, que fue galardonada con la Caméra d'Or en el festival de cine de Cannes. ${ }^{1}$ El relato cinematográfico narra el regreso de María a la hacienda que heredó de su tía Oriana. El recorrido por la antigua casa familiar es el pretexto para que María rememore el pasado, pero de manera fragmentada, dispersa e incompleta. Un inservible piano, el álbum de fotografías de la familia, un caleidoscopio, cartas de amor y demás son algunas cosas viejas que aún se conservan en las habitaciones y convocan en María el reencuentro con el pasado en el que conoció a su amable tía Oriana. De esta manera, el retorno de María se transforma en una experiencia evocadora, en la que siente que debe unir un rompecabezas al que le faltan varias piezas. No obstante, los vacíos de la memoria son sustituidos por viejas fotografías que le permiten descubrir el misterio que se encerraba en la niñez y juventud de Oriana, al lado de su medio hermano, Sergio: la relación incestuosa que sostuvieron, la cual desencadenó la ira del padre, quien asesinó a su propio hijo.

La película Oriana (1985) contiene diferentes indicios que levantan sospecha sobre la intención de Fina Torres de simplemente recrear el cuento Oriane, Tía Oriane (1975). En primer lugar, en el filme se sustituye el contexto del relato original por una hacienda venezolana. En segundo lugar, el relato se disemina en cuatro décadas claramente determinadas: 1910, 1930, 1940 y 1970. En tercer lugar, Torres (1985) muda la pintura del padre del gran salón (lugar en el que lo sitúa Marvel Moreno) al comedor y, además, cambia la indumentaria del patriarca, que representa a un distinguido burgués, por el uniforme de un militar. Para terminar, el filme inicia con el registro de un retrato de familia que no hace parte del cuento de Moreno (1975). En los eventos expuestos se revela el interés de Torres (1985) por ubicar la acción específicamente en una hacienda, en periodos de tiempo concretos, que fungen a la manera de guiños con la historia venezolana que transcurría de manera paralela a los hechos que narra el filme. En ese devenir, algunos eventos concretos son: la idea común y compartida que dejó la colonia española de que el hombre de raza blanca es, por derecho, superior a seres humanos de epidermis más oscura; el ascenso del pensamiento burgués, que influyó en la noción mujer como ángel del hogar; $\mathrm{y}$, posteriormente en el siglo $\mathrm{xx}$, el ascenso y gobierno del general Juan Vicente Gómez. Las circunstancias expuestas conformaron y produjeron formas de pensamiento que se introdujeron en las capas sociales y en el núcleo familiar.

En el relato fílmico, la pintura del padre y el retrato de familia revelan un orden ideológico y perenne, que fue constituido alrededor del patriarca y determinó relaciones de poder con su esposa, sus hijas (ángel del hogar) y las clases que estaban por debajo (el hijo ilegítimo y los peones). Torres (1985) abre los límites 
del marco de la pintura y del encuadre de la cámara fotográfica para mostrar lo oculto, aquello que se escapa al espectador que observa las imágenes, y que en el texto literario Moreno (1975) deja a la imaginación del lector. La trasescena de las imágenes en cuestión expone conflictos de poder, género y clase, que surgen de la forma en que históricamente se consolidaron, produjeron y reprodujeron las relaciones sociales en la comunidad familiar que describe el filme. Torres (1985) trasciende el microcosmos de la ficción de una historia de familia hasta una reflexión en sentido histórico. En consecuencia, se pretenden exponer los vínculos históricos y sociales en los que se circunscribe el retrato. Luego, se analiza la pintura del padre para comprender su significado dentro de la película. A continuación, se examina el retrato de familia y la tras-escena de aquel, para explicar la relación de las dos imágenes, ya señaladas, con los acontecimientos que desarrolla el filme.

\section{La importancia del retrato}

El retrato de personajes ilustres, al igual que el retrato de familia, no solo es un género en la pintura y en la fotografía, sino un documento históricos valioso, porque expone un comportamiento social y una manera de pensar; es la materialización del culto a la individualidad. El retrato, según Martínez (2004), se origina en la Antigüedad, cuando los gobiernos o las familias pudientes encargaban a los artesanos la elaboración de máscaras mortuorias para conservar vivo el recuerdo de reyes, príncipes y personajes ilustres. Las imágenes de los líderes del pasado se exhibían en los templos y en los edificios públicos, y luego en las casas de los nobles. La máscara mortuoria, y posteriormente el retrato, permite que los individuos trasciendan su propia época con sus rasgos y dignidad, ausentes del envejecimiento al que los somete el devenir de su existencia. Esa aparente dignidad y ausencia del paso del tiempo que conforma el retrato mantiene una relación de poder con la comunidad en la que intenta permanecer vigente. El retrato manifiesta que el poder es incorruptible y perenne. A propósito de lo dicho:

Escribe Elías Canetti en La conciencia de las palabras que "la situación de la supervivencia es la situación central del poder"; así también la aparición del retrato se gesta en este deseo de supervivencia de un individuo que ha adquirido identidad social y va tomando forma a partir de un ingenuo "doble" donde se ensamblan definitivamente la vida y la muerte, ser humano y sujeto, rostro y hombre, retrato y poder. (Martínez, 2004, p. 28)

Necesariamente, el retrato se constituyó en un símbolo de poder, que pasó de representar nobles y gobernantes a burgueses, debido a la capacidad adquisitiva de estos últimos. Los retratos pictóricos que se conservan en las casas sirven de testimonio a la comunidad de que en el seno de la familia hubo alguien importante. Al ser parte de la historia del clan, las imágenes de sus antepasados les permiten a los descendientes reconocer su relación con alguien único, que los 
hace sentir diferentes al resto de la comunidad. De acuerdo con Martínez (2004): "A pesar del tiempo, aún se insiste en una genealogía de la estirpe - de la que es cómplice la producción de retratos-, como menester profundo para poder ser, asemejarse y distinguirse, lo que permite que se mantengan las diferencias sociales" (p. 62). Todo aquel que ascendía quería exhibir su éxito económico y social. La clase burguesa que comenzaba a ocupar la cima de la pirámide social se creyó o quiso conformar una nueva aristocracia. De acuerdo con Martínez:

El adrezzo de los retratos reales pasa a la disposición de la representación de un sector más amplio de sujetos. El tradicional retrato de esponsales, la pose de cuerpo entero, el paisaje como lugar de poder, la importancia de la indumentaria del status social y en definitiva la estructura espacial como semántica de la identidad, confluyen en el retrato burgués, significativamente a un paso de la revolución. (2004, p. 66)

Ascender de clase significaba exhibir una corona de laureles, para mostrar la victoria alcanzada a los de abajo y a los de arriba; una corona que se tejía con la exposición de las propiedades, objetos lujosos y el encargo de retratos de familia. Particularmente, el género del retrato de familia evolucionó de los retratos pictóricos, que primero fueron privilegio de reyes y luego de la burguesía. De acuerdo con Rodríguez (1998): “La familia encontró en los mismos inicios de la fotografía su medio más amplio de constatación. La pintura de los siglos XVII y xviII recreó el retrato familiar exclusivamente entre la nobleza, los nuevos burgueses y los altos funcionarios" (árr.. 1). Padres e hijos emulaban las otrora posturas de reyes y príncipes en pinturas y, posteriormente, en fotografías. En consecuencia, los nuevos medios mecánicos y físico químicos facilitaban que, además del patriarca, también toda su prole se conservará en el retrato. “La industria fotográfica se desarrolla en estrecha relación con esa necesidad del hombre, más antigua y urgente, de 'salvaguardar su integridad más allá de la descomposición', anota Edgar Morin en L'homme et la mort (1970)" (Ansón, 2000, p. 13).

La fotografía y el retrato pictórico se constituyeron en medios para que los poderosos no sean olvidados. No obstante, un retrato pictórico es más costoso que un retrato fotográfico. Una fotografía permite obtener la imagen de manera casi inmediata, mientras que una pintura lleva días o meses de elaboración, porque el modelo debe posar pacientemente ante el pintor, que debe controlar constantemente la humedad, la luz y otras variables que pueden influir en la obra. Por lo tanto, el valor de la pintura varía también en razón de la trayectoria y experticia del artista. En muchos retratos pictóricos tiene más valor económico la firma del artista que la importancia de la persona retratada. A esto se añade que el retrato pictórico se erige en manifestación explícita de poder y tradición, más que el retrato fotográfico. En general, los retratos (pictóricos y fotográficos) de los poderosos y sus familias declaran que el ser humano necesita que la comunidad los certifique públicamente y su intento porque dicho reconocimiento permanezca en el tiempo. El éxito financiero que permite alcanzar beneficios materiales es insuficiente, porque se pretende coronar la cumbre social. Aquellos 
que no nacieron con sangre azul compran los pergaminos que lo validan ante la sociedad, con el respaldo de las arcas que les resguarda el banco.

Además de lo expuesto, una imagen manifiesta otros niveles de relación con los espectadores. El objeto fotografía, contenedor de la imagen, produce una relación especial con el observador, correspondencia de afecto o contrariedad, que hace las veces de eslabón que mantiene unido al hombre con un pasado inasible. La imagen sujeta en el presente un acontecimiento acaecido en un tiempo pretérito. Al respecto, Frank Horvat (1987) expresó: “La fotografía es la aceptación de un fragmento de la realidad por el espíritu en un instante privilegiado" (p. 169). La fotografía es la respuesta del fotógrafo a un instante de inspiración, en el que logró captar lo esencial de la vida. Apropiarse, de cierta manera, del entorno gracias a la imagen que proporciona la fotografía del mundo real manifiesta en el universo simbólico de los individuos situaciones particulares, que no se percibirían de no ser por la propiedad de congelar el tiempo. Dice Susan Sontag (2006) que la fotografía enseña un nuevo código visual, altera y amplía las nociones de lo que se debe o no observar. La fotografía también determina la manera de mirar el mundo. "Fotografiar es apropiarse de lo fotografiado. Significa establecer con el mundo una relación determinada que parece conocimiento, y por lo tanto poder" (p. 16). Poder que encierra el privilegio del fotógrafo, que por propia voluntad captura con su cámara las imágenes de personas, paisajes, cosas, y las transforma en objetos, en fotografías. "Fotografiar personas es violarlas, pues se las ve como jamás se ven a sí mismas, se las conoce como nunca pueden conocerse; transforma a las personas en objetos que pueden ser poseídos simbólicamente" (p. 31).

En una fotografía, los individuos adquieren un semblante particular, porque la cámara que los intenta captar provoca incomodidad. Todos somos actores ante el objetivo de una cámara. El individuo por ser retratado es consciente de que es observado, y por ello se siente obligado a calcular su posición con el entorno, a asumir una pose, a cambiar la actitud, porque sabe que va quedar expuesto a la vista de los demás. Un individuo que espera a que se le tome una fotografía se siente comprometido con la imagen que de sí mismo se transmitirá a la comunidad. En otro sentido, el observador que repara en una fotografía hace una lectura de lo que allí ve, para intentar comprenderla e interpretarla.

Una fotografía es un acontecimiento que solamente puede ser descifrado en virtud de la experiencia y cultura que posee el espectador. El público interpreta, deduce y produce significados, según demanda su lógica cultural. En un relato, las pinturas, fotografías, carteles, y toda imagen que se detalla, necesariamente adquieren un segundo nivel de interpretación, porque, además de proponer una imaginería sobre sí mismas, están remitiendo a algo más. La revisión de una imagen que se presenta en un espacio diegético narrativo (fílmico o literario, para este caso) debe revelar acontecimientos que remiten a relaciones de poder, relaciones afectivas, frustraciones, desengaños y diferentes conflictos que impactan a los personajes de la historia. Por lo tanto, el otro lado del poder que encierra la imagen misma es una narración que expone situaciones en las que 
entran en juego las relaciones humanas de hegemonía, dominio y sumisión, aunque toda relación sea subjetiva, pues una fotografía siempre significa algo más para aquel que tiene una relación cercana con aquella.

Ansón (2000) dice que "Las fotografías no cuentan nada, excepto cuando tienen el vínculo de la experiencia entre aquel que las posee y las personas o cosas fotografiadas. Entonces sí que cuentan, importan y narran una historia tan personal como perecedera, a merced de la memoria que desatan sus imágenes" (p. 18). Las imágenes fotográficas y pictóricas son materializaciones de acontecimientos temporales, por lo tanto, son indicios de que en el pasado ocurrió algo. ¿Qué es la fotografía sino la huella de un hecho que aconteció tiempo atrás? Aumont (1992) declara: "la imagen fotográfica es una marca, una huella. Automáticamente producida por procedimientos físico-químicos, de la apariencia de la luz en un instante dado, por lo que creemos que representa adecuadamente la realidad y estamos dispuestos a creer eventualmente que dice la verdad sobre ella" (p. 119).

\section{El retrato del padre}

La película Oriana (1985) narra la historia de María, que está radicada en Francia y una noche recibe un cable de Venezuela, en el que se le informa la muerte de su tía y la herencia que le legó. A continuación, María y su esposo se trasladan hasta la vieja hacienda familiar, con la intención de venderla. La herencia es lo que queda de un próspero latifundio, en el que se conserva una gran casa, prácticamente en ruinas. Al abrir cada ventana, la luz del día ilumina los rincones que le recuerdan a María los momentos que vivió con su tía Oriana. Entrar de nuevo al comedor significó para María el reencuentro con el gran retrato pictórico del padre de Oriana (Torres, 1985, min. 9:20). María lo había visto en el mismo lugar, años antes en su adolescencia, cuando visitó a su tía por primera vez, y ahora seguía en el mismo lugar.

El cuadro es imponente en su tamaño y tema, pues muestra al padre altivo y vestido con uniforme militar. María observa al patriarca en la pintura, y con rabia escupe sobre las flores que adornan el retrato. El suceso descrito manifiesta un conflicto entre María y su antepasado. La narración fílmica (Oriana, 1975) tiene en común con la obra literaria (Oriane, Tía Oriane, 1975) que el retrato del padre es una imagen conflictiva para María y su tía. Marvel Moreno presenta al padre solamente una vez en el cuento:

El retrato de aquel hombre de mirar airado, con el smoking cruzado por una banda de seda púrpura y dos condecoraciones prendidas a la solapa, recibía el sol de frente y estaba ya tan desteñido que algún día, decía tía Oriane, sólo sería un fantasma de cuadro entre los fantasmas de una casa sin dueño. (p. 178) 
La descripción se centra en la manera irritada con la que mira el sujeto del retrato y en la indumentaria que lleva puesta, pero no hay referencia a su fisonomía. No se sabe si la pintura representa a un joven, a un anciano, si usaba bigote... En consecuencia es un padre sin rostro.

El único rasgo humano es la mirada que manifiesta un rasgo de carácter inquisidor, autoritario. Por otro lado, la referencia a la banda de seda púrpura $\mathrm{y}$ a las dos condecoraciones revela que el padre fue un hombre importante. Particularmente, el púrpura que tiñe la banda de seda es referente de grandeza. Por ejemplo, en la sagrada Biblia constantemente se alude al púrpura para resaltar la importancia de un individuo o de un espacio sagrado que se debía investir de dignidad. El capítulo 36 del Éxodo dice: “Todos los sabios de corazón de entre los que hacían la obra, hicieron el tabernáculo de diez cortinas de lino torcido, azul, púrpura y carmesí; las hicieron con querubines de obra primorosa" (p. 95). El púrpura es uno de los colores elegidos para las cortinas que debían cubrir el lugar sagrado del tabernáculo. Asimismo, el púrpura, junto con el rojo, son los dos colores que distinguen a los cardenales de la Iglesia católica. La banda púrpura hecha de seda y las condecoraciones que lleva el padre son los elementos que determinan la importancia del hombre que está en el retrato. La descripción de la pintura deja de lado el rostro del padre, porque son más importantes las distinciones que lleva su indumentaria, ya que estas hablan por él. De esta manera, el retrato del padre exterioriza lo ya expuesto por Martínez (2008): la pose de cuerpo entero, junto con la indumentaria, conforman sobre el individuo retratado un paisaje de poder. La imagen representa el imperio del patriarca, pero no al padre de carne y hueso, porque para Moreno (1975) el padre se sintetiza en poder.

En el filme Oriana (1985), de Fina Torres, al contrario del cuento de Moreno (1975), el hombre que posa en el retrato tiene rostro y los signos que remiten al militar son opacados por el parecido fisonómico con el general Juan Vicente Gómez. De esta manera, no se está hablando meramente del poder, sino de un poder histórico. Martínez (2004) manifiesta que el retrato es "un ingenuo doble" (p. 28), en el que el hombre y el poder se unen. En el caso de Oriana (1985), el retrato que recoge las dos facetas del padre (hombre y poder) remite a la correspondencia con la figura dominante y emblemática que personificó el general Gómez en Venezuela. Es decir, Torres (1985) convoca en la pintura del padre a un individuo que en sí mismo fue paradigma de dominación. El general Juan Vicente Gómez fue una figura pública muy importante y controvertida de la política venezolana. Durante su gobierno, relata Rodríguez (1988), se inició la explotación petrolera, que generó "suficientes recursos para financiar su larga permanencia en el poder y para cancelar la deuda pública externa e interna de Venezuela". (p. 92). De acuerdo con Rodríguez, en los momentos que el general no ocupó la cabeza del Gobierno, continuó siendo el jefe máximo del Ejército y uno de los hombres más ricos e influyentes de Venezuela, que fue consultado continuamente durante diversas situaciones de la vida política. 
Figura 1. Retrato de Juan Vicente Gómez

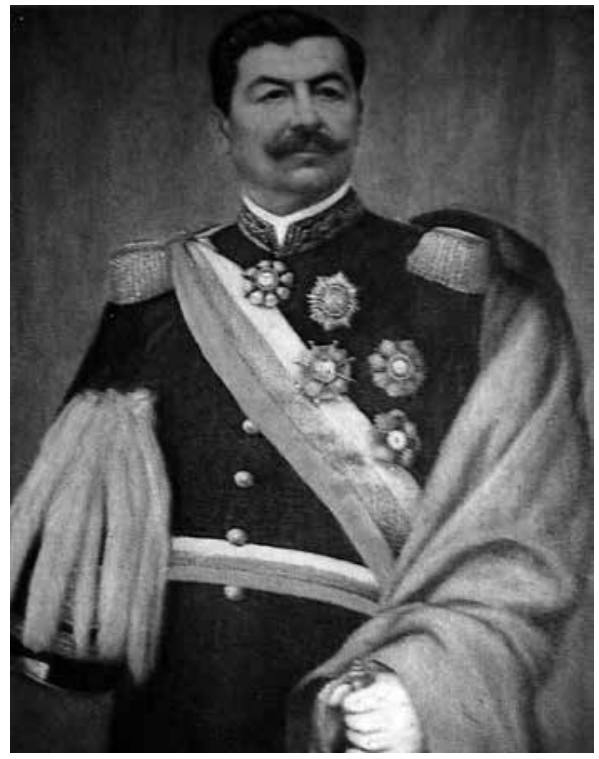

Fuente: Wikipedia (2015).

El general Juan Vicente Gómez inició su gobierno en Venezuela en 1908, un periodo en el que el país era eminentemente rural y sustentaba su economía en la agricultura. Al respecto, Cipriano (1993) dice que Venezuela seguía siendo "el mismo país de latifundios, predominantemente pre capitalista y rural" (p. 109). No obstante, la década de 1910 coincide con la búsqueda de petróleo en Latinoamérica, y los grandes emporios que buscaban yacimientos encontraron en Venezuela un territorio propicio para la explotación. Esta circunstancia produjo un cambio en una sociedad de raigambre agraria, en la que el ganado, el cacao y demás frutos del campo, que a criterio del nuevo paradigma de desarrollo eran muy humildes, fueron reemplazados por la explotación del hidrocarburo, que transformó la economía y al campesino prudente y pragmático en un sujeto ávido de riqueza.

En el escenario expuesto, el general Gómez manifiesta la manera en que el raizal se acomodó a los nuevos criterios de desarrollo "del militar vencedor y empírico, convertido en jefe político que domina el país con el primer y represivo criterio de quien administra y explota - con ayuda de mayordomos incondicionales - su propia Hacienda agropecuaria". (Cipriano, 1993, p. 110). Las nuevas circunstancias económicas, basadas en los ingresos de la explotación petrolera, no cambiaron la manera en que se gobernaba a la Nación. El general Gómez concebía el aprovechamiento económico del territorio con base en su experiencia campesina y latifundista, de manera que el ejercicio político no era muy diferente a la administración de una hacienda. A pesar de su riqueza, el general Gómez en el fondo seguía siendo un campesino, y su manera de actuar iba en armonía con su modo de pensar. Caballero (1988) dice: 
Jacinto López también se choca ante sus modos poco civiles: “La impresión que produce el nombre pesado, tosco, burdo, suspicaz, desconfiado, ignorante y estúpido." Cuando lo vio en 1909 le pareció "...un mozo de paja y cebada o un mozo de cordel. Es un rústico que parece llevar consigo la atmósfera de las sabanas, los potreros, los hatos, los trapiches, los mesones. Imaginaos a un peón en la Presidencia de la República". (p. 16)

El primer ejercicio de gobierno que ejerció el general Gómez fue sobre sus propias haciendas, y en este ámbito quien poseía la tierra decidía cómo se explotaba y cómo se repartía la riqueza. El general Gómez impuso su estilo de gobierno con base en una experiencia vital que lo determinó como individuo desde su niñez: primero, en la dureza del ámbito rural; luego, como latifundista (gamonal); y más adelante en su carrera militar, hasta llegar a la cabeza del gobierno. El devenir del general muestra que a lo largo de su vida aprendió a dominar y a hacerse obedecer. Las circunstancias sociales constituyen formas de pensamiento que determinan los actos de todo individuo. Así, los escenarios sociales condicionaron al general Gómez como gobernante; el poder económico, militar y político que acumuló necesariamente lo convirtió en una persona muy influyente. Sin embargo, dicha influencia no obró de manera ideológica (en el sentido político) en la sociedad venezolana, pues la conducta del general Gómez como gobernante manifiesta una ideología ya existente. Para muchos de los detractores del general Gómez, no se trataba de un simple gobierno autocrático, sino que en él se representaba la dominación de una clase sobre los demás.

En Con quién estamos y contra quién estamos, Betancourt reafirma que "Para los que con criterio materialista hemos analizado la historia inmediata del país, no caben vacilaciones al afirmar que en Venezuela existe la tiranía -forma agudizada de la dictadura-de una clase, y no de un hombre o de una región; de los componentes sociales de una clase, de todas las regiones del país y no de una sola región determinada, la andina. (Caballero, 1988, p. 25)

Una figura tan fuerte en vida continúa su influencia ideológica y moral después de su muerte. El general Juan Vicente Gómez y el padre de Oriana tienen en común más que el parecido fisonómico. En las décadas de 1910 a 1930, el padre vive en la hacienda junto con su familia, y ese mismo periodo corresponde al tiempo de influencia del general Gómez, que comprende de 1908 a 1935. En las décadas de 1940 y 1970, el general Gómez y el padre de Oriana ya habían muerto. La influencia del general Gómez en la vida política y social venezolana se caracterizó por el despotismo, de la misma manera que el padre de Oriana fue un déspota con sus hijos. Dichas coincidencias, y otras que se trataran más adelante, son indicios de que en el filme existe una analogía entre el poder representado en el general Gómez y el poder del padre dentro del núcleo familiar.

Para comenzar, las relaciones de poder que sostienen los hombres con los objetos que las personifican se descubren en el espacio que ocupan. En el cuento de Moreno (1975), el lugar de la pintura del padre es "el gran salón” (p. 178), y en 
el filme Oriana (1985), es el comedor. La sala o gran salón es el lugar de la casa que se utiliza para recibir a los visitantes, mientras que el comedor es un lugar más íntimo, pues allí se reúne la familia y solamente se le abren las puertas a un invitado muy especial. El escenario señalado descubre una tradición que siguen los descendientes en el hábito de cenar y los pequeños ritos que allí se manifiestan. Por ejemplo, Fidelia cambia su indumentaria casual por un uniforme negro y almidonado, para servir la mesa a su señora Oriana y a María (min. 25:48). Los comensales que se congregan a una hora precisa alrededor del comedor, la criada que viste un uniforme negro para servir los alimentos, la vajilla elegante y los cubiertos finos son objetos que conforman los rituales que invisten de solemnidad el simple acto de comer. Son actos repetitivos que mantienen una tradición que instituyó el padre, a quien se le recuerda en la pintura que preside el comedor. El padre solicitó un retrato suyo, porque su dinero, poder y orgullo lo estimularon a permanecer, de la misma manera en que lo hicieron - como expuso Martínez (2004) - los hombres ricos y poderosos de otros tiempos, que quisieron perpetuar su imagen en una pintura.

El retrato del padre, más que un simple recuerdo del hombre, es el emblema de la familia. La pintura inmortaliza al gran hombre que hizo parte de la milicia, del Gobierno, del Estado, y quien construyó toda aquella otrora riqueza material. De una u otra manera, sus herederos son deudores de una herencia económica y una tradición que sienten que se debe preservar. La luz que irradia

Figura 2. María observa que el retrato del padre permanece en el tiempo. Arriba: María adulta. Abajo: María adolescente.

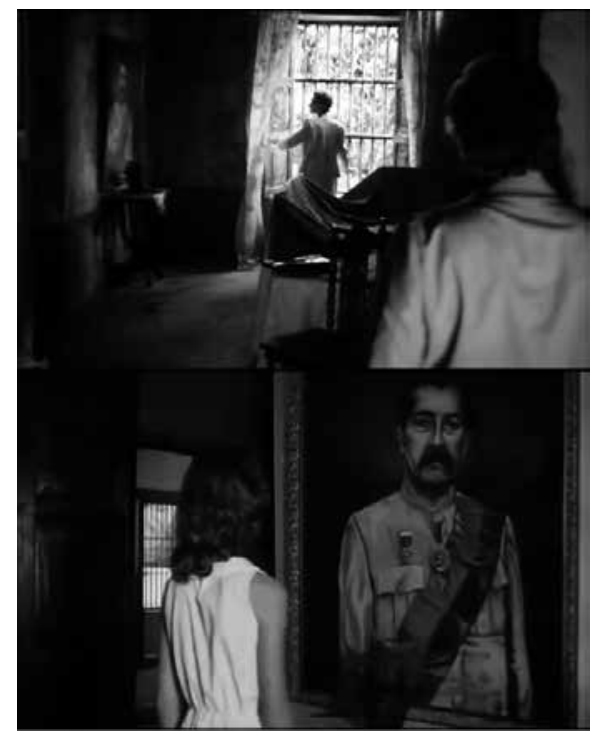

Fuente: Torres (1985). 
la obra del padre hacia la comunidad permite que el apellido de la familia se mantenga y que su presencia se sostenga omnipresente, no por él, sino por lo que representó. El retrato del padre le recuerda a su familia que a él se debe que ellos se encuentren allí, que él los alimentaba. De la misma manera que en la Iglesia católica la imagen de Jesús crucificado le recuerda a la congregación que al Señor se le debe la salvación. El cuadro del padre, a la vista de los descendientes que se reúnen a comer alrededor de la mesa, es el recordatorio de que comparten la misma "genealogía de la estirpe" (Martínez, 2004, p. 62) y que se pueden reconocer a sí mismos en su participación de un tronco común. El retrato del padre que preside el comedor ocupa un lugar desde el que parece emitir una pequeña voz que exige a los suyos mantenerse unidos en torno a un pasado que les pertenece y que fue construido sobre roca sólida. Por lo tanto, la presencia del padre es trascendental y se mantiene, aunque él ya no viva.

En la película Oriana (1985), María se reencuentra con el retrato del padre, que aún continua, impasible, presidiendo el comedor. Incluso la imagen seguía adornada con flores. La pintura del padre simboliza la prosperidad del pasado, que se debe mantener aunque esa otrora bonanza sea un recuerdo. La historia familiar se preserva en el retrato de aquel que la inició. Por ello, Oriana se encarga de que las flores frescas siempre estén engalanando el retrato. Sin embargo, solamente Oriana sabe que su padre odiaba las flores de cayena, que son las que ella pone. En el acto diligente de Oriana se expresa un sentimiento de odio hacia su progenitor.

Parafraseando a Ansón (2000), las imágenes solamente narran cuando tienen un vínculo con la experiencia de aquel que las posee. Es decir, para ella la pintura no era un mero símbolo, una cosa, pues en el retrato algo quedaba del ser que fue su padre. No se odia a un objeto, sino a un individuo. Por otro lado, María nunca conoció a su abuelo en vida, sino en la pintura que lo representaba y permanecía colgada en el comedor. María, al contrario de Oriana, no ve en el retrato a un ser, sino a una cosa, el icono de un militar de gesto adusto. Una mera imagen genera emociones, pero no el sentimiento de amor $u$ odio que une a una persona con sus semejantes. El retrato del padre es una brecha temporal que no solo separa a María de su abuelo, sino que une a Oriana con su padre. El hombre no logra que el retrato preserve su ser a lo largo de todas las generaciones, pues el tiempo agranda la distancia, y meramente queda para los herederos lo que simbolizaba.

El retrato termina por matar al hombre de carne y hueso. María nunca conoció a aquel hombre que estaba en el retrato, ella simplemente se hace una imagen que se divide entre los testimonios que escuchaba de su tía y el retrato que ve colgado en el comedor. La pintura del padre es un cuasisímbolo para María, pues intenta conciliar el imaginario legado del pasado familiar con el militar que observa en la imagen. Una figura castrense despierta recelo, porque existe el supuesto de que es quien ordena, exige, se hace obedecer y se impone sobre los demás, porque representa la ley. María observa en el retrato a su abuelo, pero para ella abuelo es simplemente una palabra, ya que del ser de carne y hueso que existió queda solamente una imagen de poder y dominio. 


\section{Retrato de familia}

La segunda imagen que propone Torres (1985) es el retrato de una familia pudiente del periodo 1910-1920. El escenario es el espacio entre los escalones y el zaguán de una gran casa, decorada con plantas palmeadas y gruesas columnas que anteceden el portón. En el centro se encuentra el padre, sentado en una silla vienesa, con las manos puestas sobre un bastón; tras él, la madre, en pie, apoya su mano derecha en el espaldar de la silla; adelante, la hija mayor está sentada en un escalón; $y$, a la derecha, de pie, se encuentra una pareja de niños. El retrato en sí mismo no se diferencia de manera significativa de otros retratos de familias pudientes de la época. Se podría afirmar que es un retrato más.

Figura 3. Retrato de familia en la película Oriana

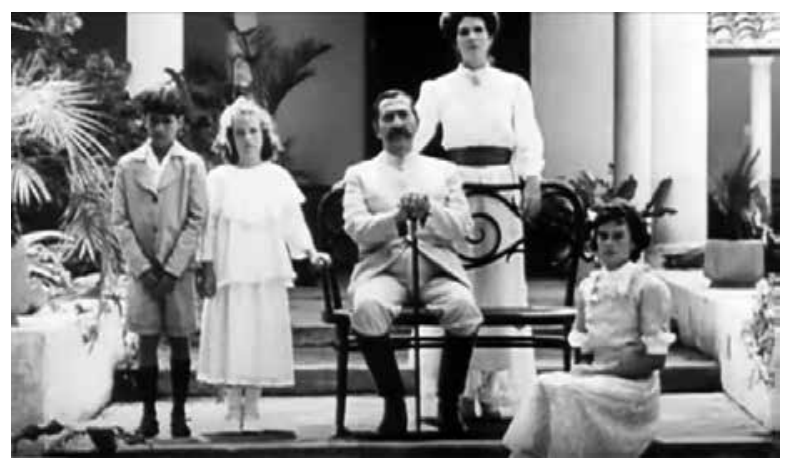

Fuente: Torres (1985).

Sin embargo, el retrato de familia en Oriana (1984) manifiesta que en dicho núcleo social existe una tradición de poder que, de acuerdo con Rodríguez (1998), se reconoce en el porte que mantienen los sujetos, entre otros elementos de la imagen. La composición piramidal en torno al padre, que se mantiene en el centro, entre la esposa y los hijos, recuerda las poses de reyes y príncipes; la casa, al fondo, emula lo mismo que fue para el aristócrata su castillo; el padre, que permanece sentado y sostiene un bastón, evoca a un rey en su trono, mientras sujeta el cetro; las mujeres y los hijos que rodean al padre son signos que lo confirman como el centro de la familia.

La fotografía también revela que la situación de la niña es diferente a la de su madre y su hermana; ellas están al lado opuesto de la composición. En la fotografía, Oriana posa su mano en la silla de su padre, mientras los otros miembros parecen estar separados de él. Entre la niña y su padre existe un lazo más estrecho que entre su esposa y su hija mayor. Oriana está a la derecha de su padre -es su favorita - y se interpone entre él y Sergio. La imagen del patriarca rodeado de su prole revela que el dueño de una gran casa, de propiedades y de dinero ahorrado en el banco no era nadie sin su núcleo familiar, sin sus vástagos, que debían asegurar la prolongación de su herencia. Los herederos del linaje posan 
junto a sus padres, como testimonio de que las raíces del árbol familiar han sido sembradas en tierra fértil y también florecerán. El retrato los presenta en y ante la sociedad.

No obstante, la tras escena muestra que las circunstancias en que se tomó el retrato rompen el orden social de la hacienda. La pequeña Oriana incluye a Sergio en la fotografía y provoca que el observador imagine que el niño es uno de los hijos del padre. La familia permanece indiferente, porque parece más importante estar dispuestos para el retrato que controlar la situación. La sumisión de la familia o consentimiento hacia lo ocurrido se mantiene, porque hay que callar, guardar la compostura, las apariencias, así sea ante los peones. El padre, dueño y señor de la hacienda, lo permite y está bien.

La puesta en escena del retrato de familia reveló que el niño (Sergio) fue introducido en el núcleo familiar por una niña de su edad. Podría no ser hijo del patrón, pero tampoco viste ropas de campesino; al contrario, parece un señorito, y el padre no se esfuerza por impedir que haga parte del retrato. El niño viste ropas formales y la confianza con que Oriana se dirige a él permite intuir que no se trata del hijo de un peón, aunque poco antes se encontraba con ellos. El cuadro tiene armonía, el color sepia mantiene el matiz, los personajes están bien dispuestos en el retrato y el vestuario corresponde con la clase que representan. Sergio no desentona con el grupo. Sin embargo, en el contexto de la imagen comentada hay más afinidad visual entre el padre y el niño que entre ellos y los demás. Las botas largas de montar que lleva el padre son correspondientes con la usanza de un acomodado gamonal. Sergio calza zapatos negros y largas medias, que casi le llegan a las rodillas, son parte de la indumentaria de un niño rico, no del hijo de un peón, que llevaría alpargatas o estaría descalzo. De igual modo, la piel del padre es del mismo tono que la del niño.

La fotografía testimonia la existencia de un conflicto. Por un lado, Sergio se encuentra en medio de dos clases: la del señor de la hacienda y la de los peones. La tras-escena del retrato demuestra que el niño no está en el lugar que le corresponde, y antes tampoco lo estuvo. Por otro lado, la fotografía manifiesta que el padre no tiene un hijo varón que perpetúe su apellido. Las hijas del padre no son raíces que se entierran profundamente en la tierra, por el contrario, son la certeza de que después de ellas no solo el apellido paterno será olvidado y ocupado por algún advenedizo, sino todo un pasado que fue construido con el sudor del padre y sus ascendientes, y que les dio el derecho de pertenecer a los de arriba.

Torres recrea en el inicio del filme un aparente hecho fortuito que determinó la fotografía: el niño no hace parte de la familia, pero el retrato testimonia que sí lo es. El filme revela más adelante que Sergio era el hijo ilegítimo del padre, que lo trajo a la hacienda y lo puso al cuidado de Fidelia. El temor del padre mantiene cerca a Sergio, porque es su único hijo varón, pero a la vez lo desprecia porque es ilegítimo. El acto inocente de la pequeña Oriana demuestra que la familia está fracturada. La transgresión del padre, y luego de Oriana, quiebra el círculo 
de la tradición que ha mantenido a la familia dentro de la sociedad. Se permitió que el pequeño Sergio, el advenedizo, se acerque demasiado a la familia.

En Oriana (1985), el tono de la piel que se asocia a determinas clases sociales, particularmente el tono más oscuro, que se afilia a los mestizos, y los derechos que se ganan con el matrimonio son los dos factores que rompen el orden traspuesto de la hacienda, y están relacionados con tradiciones e ideologías sociales que sujetan a los individuos. El retrato de familia declara que el padre y Sergio tienen un matiz de piel oscuro, muy semejante al de Fidelia y Sánchez (la criada y el peón), que contrastan con la tez clara de la esposa y las hijas. La sangre blanca, que tradicionalmente debe correr por las arterias del amo, parece no corresponder con la del padre; la tez blanca de sus hijas es herencia de la madre, lo cual indica una separación de raza en la familia.

Las circunstancias en que se daban las alianzas matrimoniales y en que se heredaron las haciendas fueron producto de acuerdos económicos necesarios para mantener la solvencia financiera de las familias. En muchas ocasiones los matrimonios eran arreglados para suplir necesidades económicas. Una familia arruinada, pero que aún conservaba su buen nombre, era patrimonio suficiente para arreglar un maridaje con quien tal vez no gozaba de apellido, pero sí de dinero. Ascender de esta manera en la escala social engendraba hijos por contrato y no por amor. Sin embargo, una unión matrimonial, bendecida por la iglesia y conveniente dentro de la sociedad, no garantizaba los frutos esperados para perpetuar el apellido paterno, mientras que una unión ilegítima sacaba de la rutina al señor y a veces favorecía el nacimiento de un varón. Los señores engendraban hijos por fuera de sus matrimonios, generalmente con campesinas que vivían en sus casas o hatos. Las circunstancias en las cuales se dieron dichas relaciones surgen de un acuerdo dentro la comunidad, no aceptado públicamente pero necesario, un pacto en el que se acepta al pardo si tiene dinero, que le concede al hombre el derecho a preferir un heredero varón, a la infidelidad, a desfogar su deseo de macho, este y todo acuerdo subterráneo que Žižek (2007) denomina "Superyó obsceno" (p. 88).

De acuerdo con Žižek (2007), la sociedad dispensa de autoridad a ciertos individuos y les permite actuar de manera no ética, porque esta tiene la idea de que aquel que tiene el poder o la autoridad puede hacer lo que desee, porque no es una persona, sino simbólicamente es la ley. El poder que le brindaba el dinero le permitía al señor tener aventuras con sus sirvientes mestizas y engendrar hijos ilegítimos. En Oriana (1985) algún antepasado muy cercano al padre fue mestizo o pardo, ${ }^{2}$ la madre o la abuela. Asimismo, las relaciones ilegítimas de los antepasados engendraron al padre de Oriana, y luego este procreó a Sergio. En consecuencia, existe un desequilibrio de clase en la familia que fue heredado $\mathrm{y}$ se mantiene.

2 Pardo era sinónimo de mestizo. "En la categoría de 'pardo' la ascendencia es incierta. Sólo sabemos que hace referencia a personas de sangre mezclada, a diferencia de otras denominaciones raciales relacionadas con la población de origen africano" (Castillo, 2001, p. 132). 
En Latinoamérica existen familias blancas y mestizas en cualquiera de los niveles de la escala social. No obstante, en el imaginario colectivo, el mestizo de piel morena tradicionalmente ha sido homólogo de la clase más baja. Al fin y al cabo, un tono de piel que no sea blanco le recuerda a la comunidad que en el pasado se produjeron juntes raciales entre blancos, africanos e indígenas. Dicha imagen mental aún se mantiene en nuestra sociedad.

En el contexto latinoamericano, proviene del pensamiento colono español, Stolcke (2009) declara que desde el medioevo tardío se originó "la doctrina teológico-moral de la limpieza de sangre" (árr.. 10). La limpieza de sangre garantizaba la identidad cristiana y su jerarquía nacional respecto a los moros, los judíos, los herejes y cualquier convicto por la Inquisición. Pues bien, el cruce étnico que se produjo en la América española fue una situación en sí misma espuria para la sociedad blanca que ejercía la hegemonía. Dicha situación bien pudo estimular el abandono de los niños mestizos que eran engendrados, pero no reconocidos ni bautizados; ya que no eran deseados, se ubicaron en la esfera social más baja. De acuerdo con Stolcke (2009), el Gobierno español institucionalizó la categoría de "descendencia mixta" (árr.. 17), que intentó proveer de estatus sociojurídico a los mestizos, pero este siguió siendo despreciado. Un niño mezclado no sabía quién era su padre, de dónde venía, a cuál raza pertenecía, y desde muy temprana edad era destinado a ejercer oficios serviles.

Friedemann (1993) expresa que en el periodo colonial, la Nueva Granada se rigió en un régimen de castas y los derechos estaban preestablecidos: "De manera que solamente los 'límpidos de sangre' desempeñaban trabajos considerados nobles" (árr.. 9). Un ejemplo de lo que ocurría con los mestizos en las diferentes colonias de españolas, y que podría ser paradigmático, es el de la población venezolana del Buen Jesús de Petare. De acuerdo con Gómez (2011), en 1801 el sacerdote Pablo Antonio Romero llevó a cabo un censo en Petare, y pudo identificar los oficios que desempeñaban los mestizos: jornaleros, pulperos, alarifes, herreros, músicos, curanderos y demás. Si bien el paulatino pero generalizado aumento de juntes raciales provocó que los mestizos también tuvieran que ejercer actividades antes reservadas para los blancos (mercaderes, arquitectos, médicos, entre otros), la nueva raza seguía propiciando tensión en las comunidades blancas. Al respecto, Friedemann (1993) expone:

La referencia a "lo blanco" en las clasificaciones de cuarterones, quinterones o tercerones o la ausencia del mismo en el caso del zambo, indio o negro es bastante explícita. El mestizaje que fue así sustento en la construcción de la sociedad de castas cuyo tope ideal era ser o convertirse en blanco, llevaba implícita la ideología del blanqueamiento. Que a su vez se convirtió en un proceso socio-genético. (árr.. 4)

Aunque la mayoría de la población latinoamericana es mestiza, en todos los niveles sociales, persiste la creencia de que "aunque la mona se vista de seda mona se queda", porque se sigue asociando el mestizaje a las clases más bajas. En el contexto colombiano, los motes de indio, pueblo, chusma o levantado son 
atributos que provienen de dicha manera de pensar. La idea de que perdure el imaginario de que la raza blanca, por su origen europeo, constituye un ideal asociado al progreso individual o que pueda facilitar el ascenso social es una situación que necesariamente desencadena tensiones raciales, así no se habite en un régimen declarado racista. No es aventurado deducir que si un pardo ascendía en la pirámide social tampoco hubiera permitido que lo llamaran así, y menos que un hijo suyo tuviera una relación íntima con alguien de esta clase. Un mestizo debía relacionarse con los suyos, porque la sociedad lo condicionaba a mantener su lugar.

En Venezuela, durante el régimen de Gómez, la sociedad sentía frustración e impotencia hacia el dictador y sus cómplices, que se expresaba en los sentimientos hacia el mezclado. Los proscritos del Gobierno, que en su mayoría fueron políticos e intelectuales, expusieron en diferentes escritos y pasquines clandestinos sus críticas hacia el general Gómez. Dicha valoración, además de manifestar lo que la comunidad sentía hacia el general, también lo hacía hacia el fenotipo que encarnaba. Caballero (1988) presenta una de las tantas descripciones que se hicieron sobre el dictador:

Doce años más tarde, en el periódico La reforma social, Jacinto López, imprime su propia placa en estos términos: “El ‘General' Gómez es un hombre de 60 años sonados, regular de estatura, lacertoso, carrilludo, de ojos pequeñitos, de labios gruesos, pálido, falto de frente. La mezquindad de la frente es el rasgo distintivo y dominante de su fina fisonomía. Su tipo todo grita a leguas al mestizo" (p. 14).

La descripción de Gómez describe de manera general a un mestizo, pero reducido en cualidades respecto a alguien de raza blanca. Los ojos pequeñitos son herencia del antepasado indígena, reflejan malicia, y la frente escasa le atribuye falta de inteligencia; parece que la maldad de Gómez emanara de su ascendencia. Por ello, la crítica que se le hace se manifiesta en términos raciales. Se puede inferir que dentro de la mente de Jacinto López se escucha la frase "Un mestizo está gobernando y es la causa de nuestras desgracias".

\section{En defensa de la familia}

En el mundo oscuro de los adultos son comprensibles los códigos de separación de clases. No obstante, en el universo infantil no es evidente el "superyó obsceno" (Žižek, 2007, p. 88), que rige los signos sociales y permite la perversión de los valores que se pretenden mantener. En la familia de Oriana surge el desequilibrio, porque los hermanos de sangre no crecieron conscientes de que eran hermanos, sino amigos. Los amigos crecen y lo que en la pubertad era un amor inocente se transforma en amor carnal, amor que no podía permitirse entre individuos de clases diferentes, y menos entre sujetos con vínculos de consanguinidad. La amistad entre los jóvenes era descalificada por el padre, pero Oriana y Sergio imaginaban que se debía a la inconveniencia de pertenecer a dos clases diferentes, 
a la cercanía de Sergio con los sirvientes. Públicamente no eran hermanos, aunque la comunidad lo sabía. La ambivalencia de esta ley determinó que para Oriana y Sergio nunca fuera clara ni comprensible en toda su dimensión, incluso después de conocer la verdad de sangre que los unía. Pero ni la ley erigida por la sociedad ni la verdad son razones suficientes para cambiar los sentimientos que han surgido ni para frenar el deseo. La ley de la conveniencia es dejada de lado por la ley del instinto, que los adolescentes sí comprenden.

Dentro del orden de la época, todo padre esperaba llevar a su hija virgen al matrimonio, pues garantizaba que la novia era digna. Para ello era necesario que dentro del acervo católico de las familias adineradas las señoritas se ajustaran a lo que la sociedad esperaba de ellas. Por un lado, debían mantener las buenas costumbres en la etiqueta y en las relaciones con los padres, los esposos, los amigos. Por el otro, ella era la responsable del hogar, de educar a sus hijos, de inculcar en ellos la moral y alejar a las hijas del demonio del erotismo. La madre era el ángel del hogar y el ideal que se esperaba que toda mujer debía alcanzar. Dicho ideal de mansedumbre femenina, de acuerdo con Esteban (2000), surgió en Europa en el siglo xix y se asocia al afianzamiento de la burguesía como clase social hegemónica, que ponía distancia con la aristocracia y las clases trabajadoras. Ya que la burguesía era la clase más poderosa e influyente, dueña del comercio y la industria, se impusieron sus principios en casi todo el orbe. En América, los países que se emancipaban de Europa querían hacer parte de este nuevo mundo; por ello, acogieron aquellas nuevas corrientes de pensamiento que creían que los podrían acercar a los ideales del mundo civilizado, por ejemplo, el ángel del hogar. Aunque cada cultura adaptó los nuevos valores a sus circunstancias particulares, también hubo algunas coincidencias. De acuerdo con Cantero (2007), Occidente coincidió en que la mujer estaba reservada al espacio privado y doméstico del hogar, a administrar la casa, a criar a los niños y agradar a su esposo:

Una vez más afloran las dos cualidades que en este momento se demandan a las mujeres: amor y sacrificio; las mismas que durante siglos ellas habían venido desarrollando con su familia, siempre - tanto en siglos anteriores como en estos momentos- como un deber que es justificado desde la fuerza que dicta la naturaleza inferior de la mujer. (p. 37)

El ángel del hogar es una paradoja que nace de la creencia de la naturaleza inferior de la mujer, pero que a la vez le da la fuerza y el soporte para cargar las dos virtudes que le son propias: amor y sacrificio. Estos valores morales obligan a la mujer a sublimarse en entidad escatológica cristiana, la fuerzan a prescindir de lo mundano para exigirle transformarse en un espíritu y, en tanto espíritu, ser invisible e intangible.

En Oriana (1985), ¿dónde se encuentra ese ángel del hogar que se llama madre, ¿dónde esa imagen de mujer ideal al lado de su esposo? A lo largo del filme, la madre y la hermana mayor son dos figuras efímeras, casi etéreas, que apenas 
se alcanzan a percibir en la escena del retrato; no intervienen ante el capricho de Oriana ni en la escena en la que el padre le enseña a Sergio y disparar. La explicación por la cual la madre y la hija mayor tienen una presencia tan efímera es porque son lo que deben ser, ocupan el lugar que deben ocupar, son discretas, como debe ser todo ángel del hogar, por ello no representan un cambio dentro del orden de la hacienda.

La madre de Oriana se mantiene ausente, mientras que Fidelia parece suplir esta ausencia. Muchos niños eran criados por las nodrizas y sirvientes, mientras las madres se ocupaban de labores más adecuadas para un ama de casa de sociedad. Dadas las circunstancias, podía haber más familiaridad con la nana que con la propia madre, pero a la manera de una criada, cuyos largos años al servicio de su señora le confieren autoridad y afecto. Fidelia protege, aconseja, ordena, es amorosa, cocina, hace el aseo y obedece; ella podría representar un modelo materno, pero no es la madre, es la criada. Bajo este contexto, ¿querría Oriana ser el ángel del hogar?

Es tan sutil la presencia de la madre y de la hija mayor, que se torna casi ausente, mientras que la presencia del padre es constante y vigorosa. Un padre que, aún después de muerto, permanece en su herencia material y moral, en el carácter recio que exhibe el retrato, en los recuerdos y en los diálogos que surgen entre Oriana y María. ¿Oriana no percibe en su padre una imagen más poderosa? En el filme, el padre permanece vigente al lado de sus hijos y es quien los instruye. Permite que Oriana juegue en su estudio, incluso con armas, la sostiene sobre sus rodillas mientras hojea el atlas y la alza en sus brazos para llevarla dormida hasta el dormitorio. Por su parte, a Sergio lo hace trabajar igual a un peón, le enseña a disparar y a mantener el control mientras sostiene una lata que va a servir de blanco de sus disparos. Se podría afirmar que el terrateniente se comporta como se esperaría que lo hiciera un padre de la época, amoroso con su hija, pero duro con su hijo para que sea un hombre.

El padre educa, reprende y se hace obedecer, él es la ley. La función del padre con sus hijos es muy semejante a la que en la Colonia sostuvo con sus súbditos

Figura 4. Oriana y el demonio del deseo. Izquierda: la pequeña Oriana observa el garañón que intenta aparearse. Derecha: Oriana adolescente observa a Sergio.

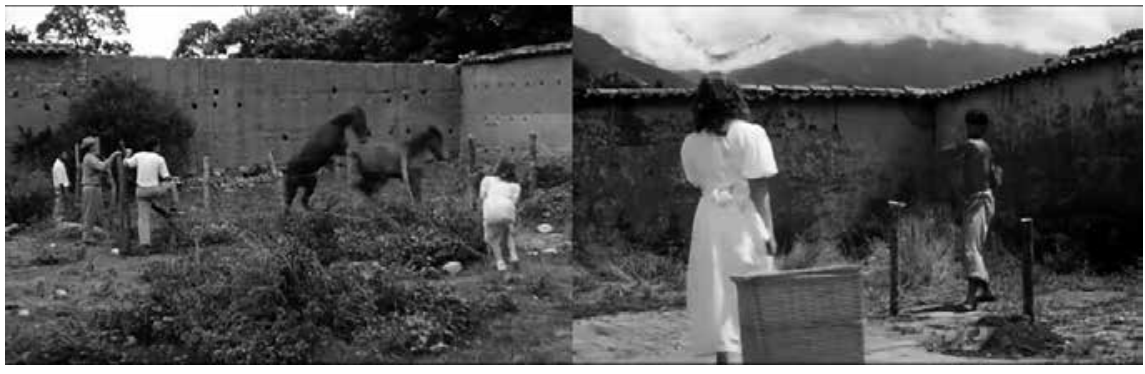

Fuente: Torres (1985). 
americanos la Corona española. El Gobierno caracterizó a los mestizos y les concedió derechos de blancos, pero también de indios. Era lo más justo, si por sus venas corría la mezcla de las dos razas. De la misma manera, el padre intenta proporcionar a cada uno de sus hijos el privilegio que ello conlleva, pero a la vez mantiene la separación entre Oriana y Sergio, entre la legítima y el mestizo, que no termina de ser aceptado por su condición de no blanco.

El español y sus hijos estaban convencidos de que eran los ciudadanos legítimos, porque eran puros de sangre, y ello les permitía ostentar derechos y privilegios. En el mismo sentido Oriana crece con todas las prerrogativas que le proporciona el padre (incluso, ella podría deducir que era la heredera de su legado, incluyendo su ley). A cambio de la imagen materna que le permitiría a Oriana verse a sí misma un futuro ángel del hogar, está el espejo de su padre recio, que le enseña la manera de actuar. La escena en la que el garañón intenta tomar a la yegua es ilustrativa del pensamiento que se conformó dentro de la mente de Oriana. El padre, en un acto impulsivo, aparta a la pequeña Oriana del demonio del sexo, expuesto en las bestias que intentan aparearse. A continuación de esta escena, el padre lleva a la niña a su estudio, la mira directo a los ojos y entonces le expresa: "Cómo me alegra que no llores" (min. 36:52).Luego la deja encerrada.

Oriana comprendió la airada reacción del padre - que en principio parece un acto impulsivo - mediante un acto de fortaleza que agrada a su padre (ella es lo que él espera). El padre se siente orgulloso porque su hija no llora, que es lo que posiblemente esperaría de un hijo varón. Por su parte, Sergio no es igual a su hermana; su condición es ilegítima, su tez es parda y tampoco es igual de recio, a pesar de los esfuerzos del padre. Sergio se siente muy inferior a su familia blanca; en la escena de la fotografía de familia, es Oriana quien toma la iniciativa y el padre, quien consiente.

El evento del semental está unido con otra situación que ocurre años después. En el mismo lugar ya no se encuentra la bestia, sino Sergio, que clava los postes de una cerca mientras Oriana pasa a su lado para observarlo con discreción. La situación revela que Sergio y Oriana son ahora los poseedores del demonio del deseo. Sin embargo, las situaciones que se desarrollan a continuación no parecen estar relacionadas con el deseo ni el tabú del incesto, sino con el lugar que ocupan Oriana y Sergio dentro de la familia. La principal preocupación del padre son sus hijos y su tierra. Una vez se han descubierto las inclinaciones de los dos hermanos, el padre confronta a Sergio: "Llevas viviendo dieciocho años en esta familia y no conoces cuál es tú lugar”. “Cuál es?” - Sergio pregunta-. "Ninguno" - responde el padre (min. 1:04:25).

Es una pregunta retórica, el padre siempre ha sabido la respuesta; para él, Sergio no es ni será uno de los suyos. Por su parte, Sergio no ha comprendido cuál es exactamente su lugar, siempre ha sido un peón con un poco más de privilegios que los demás. La exigencia del padre presiona al chico a prometerle que se va alejar de la hacienda. Oriana conoce las intenciones de su padre y la decisión de Sergio, y enfrenta a aquel. En el diálogo que se desarrolla a continuación 
se trata el tema de la tierra y del amor. El argumento de Sergio es: "No tengo derecho a estas tierras" (min. 1:05:28), pero le siguen tres enunciados de Oriana: “Ni a las tierras ni a la hija, ¿verdad?” (min. 1:05:47), “ ¿a qué le tienes miedo?, ¿a sus tierras o a su hija?" (min. 1:05:56), "sí, eres como Fidelia, un peón, un lacayo" (min. 1:06:02).

El tema de la tierra trasciende el tema del amor, la tierra siempre está presente, porque es lo más importante. La tierra es el lugar en el que la familia ha plantado sus raíces. Si Oriana afirma de manera categórica: “Ni a las tierras ni a la hija, ¿verdad?", es porque ella y la tierra son lo mismo. Oriana se hace a sí misma igual a la tierra, porque es hija de su padre y el padre es la tierra. De la misma manera, las preguntas que siguen ("¿a qué le tienes miedo?, ¿a sus tierras o a su hija?") no son un dilema, más bien son la revelación de que Sergio teme tomar las tierras o a la hija, que son lo mismo, porque sabe no son suyas. La posible intención de Sergio de poseer la tierra es adueñarse de la mujer prohibida. En la última afirmación de Oriana, es claro que considera a Fidelia una sirviente, no una familiar; asimismo, le recuerda a Sergio lo que él ya sabe: es un desterrado, un sin tierra. En consecuencia, la interpelación que Oriana le hace a Sergio para siga a su lado no es un llamado al amor, es una orden, ella es la señora y él, un peón.

La decisión de Sergio de quedarse o retirarse es continuar en el destierro eterno al que están condenados los de su clase. No tiene sentido ocupar las tierras secas de Caño Largo, ni las tierras fértiles de su padre, ni poseer la juventud de su hermana. Porque su padre, su hermana y él mismo saben que siempre seguirá siendo un lacayo. La juventud y la tierra es el futuro ideal que Oriana le antepone a Sergio. No obstante, ella quiere tomar a Sergio, así que ordena y se hace obedecer, de la misma manera en que ha visto actuar a su padre. La respuesta apocada de Sergio: "Yo soy tu hermano y él es mi padre" (min. 1:06:15) solamente encuentra la arrogante réplica de la adolescente en un interrogante vacío: "¿Y?”, una incógnita que ninguna respuesta puede colmar. ¿Y? Simplemente significa lo quiero y eso basta.

Oriana lleva la iniciativa, exige, es hija del patrón, es legítima, es blanca y sigue la ley de su padre. Oriana no es la amante, es la señora, y Sergio la obedece, al igual que siempre ha obedecido a su señor. El capricho de Oriana y el deseo de los adolescentes son auténticos, comprensibles, la juventud actúa con insensatez. Sin embargo, la situación expuesta es el resultado de la manera en que los jóvenes amantes fueron educados desde niños; ellos actuaron en coherencia con el dogma que les fue impuesto dentro del orden de la hacienda. Para el señor de la hacienda, Sergio era el hijo natural y Oriana, la hija consentida; aunque rebelde y caprichosa, era su ángel.

La relación entre Oriana y Sergio fue permeada por un mandato aprehendido, pero mal interpretado. Oriana cree que es la heredera de su padre, de su tierra, privilegio y dominio. Si Oriana hubiera sido un hombre, se habría aceptado su capricho, pues lo demanda el Superyó obsceno por el poder que detenta el amo. El niño que hubiera nacido de esta relación habría crecido de la misma manera 
que creció Sergio, aunque fuera fruto del incesto. Sin embargo, Oriana no es el señor, el señor es su padre, y él decide el destino de sus hijos.

El error de Oriana fue creer que podía actuar de la misma manera que lo hubiera hecho un hijo varón. Ella se creyó heredera de una ley que estaba hecha para los hombres. Las manos blancas de Oriana que recorren la espalda parda de Sergio son la ruptura del orden patriarcal que el terrateniente debe recomponer. El padre asesina a Sergio, de la misma manera que lo hubiera hecho con una serpiente venenosa. Sergio, antes que ser el hijo del patrón, es un mestizo, fruto de un pasado oscuro. El acto del padre no fue producto de un impulso irresistible que le nubló la conciencia, fue un episodio frío y calculado. Se comprende en la manera en que el padre observa fijamente a su hija, después de cometer el filicidio. En ese momento Oriana comprende que ella no es el padre. Él quiso sorprender a los amantes, para dar fin a una situación embarazosa que prometía salírsele de las manos; él quería que su hija presenciara la manera en que respondía a su propio mandato y resolvía las cosas, quería que ella comprendiera que solamente él era la ley. Para Fina Torres (1985), el padre es un dictador y castiga como tal: Oriana es condenada a estar encerrada, que es lo mismo que enviarla a prisión, y Sergio es desterrado y luego asesinado.

\section{Conclusión}

En el filme, el padre muere y su hija debe ocupar su lugar. Sin embargo, no se transforma en él; por el contrario, sigue su ley. Oriana se torna en una correcta señora que cuida los rosales, teje en las tardes, interpreta el piano y lee en las noches; ella se transforma en el ángel del hogar para el que estaba destinada. El ángel del hogar era la madre, y aunque para la comunidad Oriana no tuviera hijos, era una respetable señora soltera; ella debía seguir el credo social del que el padre fue fruto.

Para Oriana, la infracción debía permanecer oculta de la sociedad dentro de las duras paredes de la hacienda, pero apartada de la casa grande, escondida en la intimidad de una de las habitaciones de los peones; allí debía vivir el vástago de su abyección, el hijo que engendró con Sergio. De esta manera, continúa la ley del padre, siempre presente en el retrato y en el dogma que Oriana debe seguir cumpliendo para mantener el lejano orden que instituyó su familia.

La herencia que Oriana le legó a María hace parte de un mundo lejano que pertenece y está varado en el pasado. Se distancia del mundo moderno al que pertenece María, y con el que posiblemente sueña el hijo de Sergio, a través de las fotografías de lugares lejanos que pega en las paredes de su habitación. Es un orden antiguo que María aún percibe en la casa vieja y en Sánchez, el peón que siempre parece haber sido parte de aquel lugar.

Oriana deja que todo se derrumbe a su alrededor, porque ella misma y la hacienda pertenecen a un pasado que no es posible en el presente. El legado del pater 
familias $^{3}$ se seguirá recordando en el retrato que preside el comedor. El legado de María es comprenderlo, para permitir que su primo, el único vínculo vivo con ese pasado, sea sepultado junto con la hacienda. Solamente el tiempo tiene la capacidad de cubrirlo todo, como el polvo, hasta hacerlo desaparecer, para que la sociedad no descubra la vergüenza de su familia.

\section{$\mathbf{R}_{\text {eferencias }}$}

Amunátegui Perelló, C. F. (2006). El origen de los poderes del "paterfamilias" I: El "paterfamilias" y la "patria potestas". Valparaíso: Ediciones Universitarias de Valparaíso. Recuperado de http://www.scielo.cl/scielo.php?script=sci_ar ttext\&pid=S0716-54552006000100002

Ansón, A. (2000). Novelas como álbumes: fotografía y literatura. Murcia: Mestizo.

Aumont, J. (1992). La imagen. Barcelona: Paidós.

Caballero, M. (1988). "El hombre Gómez. Un retrato enemigo". En E. Pino Iturrieta y R. Méndez (eds.), Juan Vicente Gómez y su época (pp. 11-26). Caracas: Monte Ávila.

Cantero Rosales, M. A. (2007). De "perfecta casada" a "ángel del hogar" o la construcción del arquetipo femenino en el XIx. Recuperado de: http://www.tonosdigital. es/ojs/index.php/tonos/article/viewFile/142/116

Castillo Palma, N. A. (2001). Cholula, sociedad mestiza en ciudad india: un análisis de las consecuencias demográficas, económicas y sociales del mestizaje en una ciudad novohispana (1649-1796). México: Plaza y Valdés.

Cipriano, L. (1988). “Gómez y el agro”. En E. Pino Iturrieta y R. Méndez (eds.), Juan Vicente Gómez y su época (pp. 109-138). Caracas: Monte Ávila.

Esteban, N. (2000). El ángel del hogar y sus demonios. Ciencia, religión, género en la España del siglo xix. Historia contemporánea, (21), (363-394). Recuperado de http://revista-hc.com/includes/pdf/21_05.pdf

Festival de Cannes, versión 38. (1985). Un Certain Regard. Oriana. Recuperado dehttp://www.festival-cannes.com/en/archives/ficheFilm/id/a19569a0-4fc44b07-9986-012ed926ca38/year/1985.html

Freites, Y. (2008). Relaciones científicas de medicina veterinaria venezolana con sus pares latinoamericanos: México y el Cono Sur (1933-1955). Hist. Ciênc. Saúde-Manguinhos, 15(2), 497-518. Recuperado de http://www.scielo.br/

3 Es pater familias toda persona de sexo masculino que no se encuentra sometida a potestad ajena, independientemente del hecho de que tenga o no hijos o de la edad que posea (Amunátegui, 2006, Cap. 3, párr. 2). 
scielo.php?script=sci_arttext\&pid=S0104-59702008000200018\&lng=en\&tl ng=es. 10.1590/S0104-59702008000200018

Friedemann, N. (1993). “Castas, mestizaje y blanqueamiento". En La saga del negro: presencia africana en Colombia. Bogotá: Instituto de Genética Humana, Pontificia Universidad Javeriana. Recuperado de http://www.banrepcultural.org/blaavirtual/antropologia/la-saga-del-negro/castas-mestizaje

Gómez Castillo, S. M. (2011). Blancos, mestizos y pardos: notas sobre convivencia en el pueblo de doctrina del buen Jesús de Petare. Tiempo y Espacio, 21(56), 95-122. Recuperado de http://www.scielo.org.ve/scielo. php?pid=S1315-94962011000200005\&script=sci_arttext

Horvat, F. (1983). En F. Espluga (ed.), La naturaleza y los viajes ii. Enciclopedia Salvat de la fotografía creativa: para descubrir paso a paso los secretos de la fotografía. Barcelona: Salvat.

Martínez Artero, R. (2004). El retrato: del sujeto en el retrato (Vol. 77). Barcelona: Montesinos.

Moreno, M. (1975). Oriane, tía Oriane. Eco. Revista de la Cultura de Occidente, 29(176), 172-182. Reina, C. y Valera, C. (1960). La Santa Biblia Edimburgo: Sociedades Bíblicas Unidas. [La antigua versión, de Casiodoro De Reina (1569), está revisada por Cipriano De Valera (1602). Otras revisiones son de 1862, 1909 y 1960].

Rodríguez, G. F. (1988). "Perfil de la economía venezolana durante el régimen gomecista". En E. Pino Iturrieta y R. Méndez (eds.), Juan Vicente Gómez y su época (pp. 81-107). Caracas: Monte Ávila.

Rodríguez, F. (1996). Retratos de familia: imágenes visuales del entramado social. Credencial Histórica, 84. Recuperado de http://www.banrepcultural. org/node/32426

Sontag, S. (2005). Sobre la fotografía. México: Alfaguara.

Stolcke, V. (2009). "Los mestizos no nacen sino que se hacen". Avá 14(0-0). Recuperado de http://www.scielo.org.ar/scielo.php?pid=S1851-16942009 000100002\&script=sci_arttext

Torres, F. (1985) Oriana [Película]. Arion Productions / Pandora Films.

Wikipedia.org. (S. f.). Juan Vicente Gómez. Recuperado de https://pl.wikipedia. org/wiki/Juan_Vicente_G\%C3\%B3mez

Žižek, S. y Antón A. (2007). En defensa de la intolerancia. Recuperado de http:// www.resistenciavegana.es/descargas/Fanzines\%20Variados/Tematica \%20 Lucha\%20Social/En\%20defensa\%20de\%20la\%20intolerancia/En\%20defensa\%20de\%20la\%20intolerancia.pdf 